\title{
ANALISIS HUKUM ISLAM TERHADAP LEMBAGA PENJAMIN SIMPANAN (LPS) BAGI NASABAH PENYIMPAN DANA MENURUT UNDANG-UNDANG NOMOR 24 TAHUN 2004 TENTANG LEMBAGA PENJAMIN SIMPANAN
}

\begin{abstract}
Abu Azam ${ }^{1}$
Abstract

Deposit Insurance Corporation (LPS), is an independent agency, which serves depositor guarantee deposits and actively participates in maintaining the stability of the banking system in accordance with their authority. In carrying out these functions, LPS has the task, among others: (1) formulate and determine policy implementation of deposit insurance, (2) implement deposit insurance, (3) formulate and determine policy in order to actively maintain the stability of the banking system, (4) formulate, define, and implement Bank settlement policy that does not affect systemic failure, and (5) implement the handling of Bank Failure systemic impact. In the framework of legal protection of depositors under the Act LPS, LPS not really get the protection of the law, particularly in relation to public law between LPS with depositors. LPS is not known in Islamic law, but is known to an agency that has one function as LPS is Baitul Mal wat Tamwil (BMT), which has been known in the economic traffic of Islam since the time of the Prophet. BMT position of Islamic law, are: First, a public law institution which is engaged in the general field, not individually. Baitul Mal not only handles most aspects of economic activity of the people, but an agency in charge of all the inflows and outflows of the Islamic government (caliphate). Second, part of the state institutions in charge of finance income and expenses. There are differences between the LPS and the Baitul Mal as deposit insurance agencies, namely: First, LPS in the conventional banking system, only income comes from one source that is also designated bank customers and only for customers peyimpan funds. While the concept of Baitul Mal, Baitul Mal income from various sources in accordance with the laws of Personality', the designation/ expenditures must be in accordance with what has been established by the Islamic rules' of qathi'/definite. Second, LPS as a deposit insurance agency by taking the source of funds from depositors and one penggunaa is a deposit guarantee for the customers themselves in the perspective of Islamic law has a narrower meaning,
\end{abstract}

\footnotetext{
${ }^{1}$ Abu Azam al Hadi adalah Dosen Fakultas Syari'ah IAIN Sunan Ampel Surabaya. Alamat kontak: tt_titik@yahoo.com.
} 
because only part of the field Fa'i BMT-Kharaj, especially the section-control state budget general financial guarantor institutions (LPS).

Keywords: deposit insurance corporation (LPS), depositors, Baitul Mal wat Tamwil (BMT)

\begin{abstract}
Abstrak
Lembaga Penjamin Simpanan (LPS), adalah suatu lembaga independen, yang berfungsi menjamin simpanan nasabah penyimpan dan turut aktif dalam memelihara stabilitas sistem perbankan sesuai dengan kewenangannya. Dalam melaksanakan fungsi tersebut, LPS memiliki tugas, antara lain: (1) merumuskan dan menetapkan kebijakan pelaksanaan penjaminan simpanan; (2) melaksanakan penjaminan simpanan; (3) merumuskan dan menetapkan kebijakan dalam rangka turut aktif memelihara stabilitas sistem perbankan; (4) merumuskan, menetapkan, dan melaksanakan kebijakan penyelesaian Bank Gagal yang tidak berdampak sistemik; dan (5) melaksanakan penanganan Bank Gagal yang berdampak sistemik. Dalam rangka perlindungan hukum terhadap nasabah penyimpan dana menurut UU LPS, LPS belum benar-benar mendapatkan perlindungan hukum, khususnya dalam hubungan hukum publik antara LPS dengan nasabah penyimpan dana. LPS tidak dikenal dalam Hukum Islam, tetapi dikenal suatu lembaga yang memiliki salah fungsi sebagaimana LPS yaitu Baitul Mal wat Tamwil (BMT) yang telah dikenal dalam lalu lintas perekonomian islam sejak jaman Rasulullah saw. Kedudukan BMT dalam Hukum Islam, adalah: Pertama, merupakan lembaga hukum publik yang bergerak dalam lapangan masyarakat umum, bukan secara individu. Baitul Mal tidak hanya menangani sebagian aspek kegiatan ekonomi umat, melainkan sebuah lembaga yang mengurusi segala pemasukan dan pengeluaran keuangan dari Pemerintahan Islam (Khilafah). Kedua, bagian dari institusi negara yang mengurusi pemasukan dan pengeluaran keuangan negara. Terdapat perbedaan, antara LPS dan Baitul Mal sebagai lembaga penjaminan simpanan, yaitu: Pertama, LPS dalam sistem perbankan konvensional, pemasukan hanya berasal dari satu sumber yaitu nasabah bank dan peruntukkan juga hanya bagi nasabah peyimpan dana. Sedangkan dalam konsep Baitul Mal, pendapatan Baitul Mal diperoleh dari berbagai sumber sesuai dengan hukum-hukum syara', maka peruntukkan/pengeluarannya pun harus sesuai dengan apa yang telah ditetapkan oleh hukum syara' yang bersifat qathi'/pasti. Kedua, LPS sebagai lembaga penjamin simpanan dengan cara mengambil sumber dana dari nasabah penyimpan dana dan salah satu penggunaa adalah sebagai penjaminan simpanan bagi nasabah itu sendiri dalam perspektif
\end{abstract}


Hukum Islam memiliki makna yang lebih sempit, karena hanya bagian dari BMT yaitu bidang Fa'i-Kharaj, khususnya seksi anggaran belanja negara-pengendalian umum-lembaga penjamin keuangan (LPS).

Kata Kunci: lembaga penjamin simpanan (LPS), nasabah penyimpan dana, baitul mal wat tamwil (BMT)

\section{Pendahuluan}

Sistem Hukum Islam yang bersumber utama dari al-Quran pada dasarnya mengatur semua aspek yang berkaitan dengan hubungan yang bersifat vertikal (hablu minallah) dan hubungan yang bersifat horizontal (habluminannas). Dalam kaitannya dengan hubungan yang bersifat horizontal (habluminannas) dalam Islam salah satunya dikenal dengan istlah mu'amalat yaitu tata tertib hukum dan peraturan mengenai hubungan sesama terutama terkait dengan masalah jual-beli, sewamenyewa, hukum perikatan, dan hubungan ekonomi dan bisnis pada umumnya.

Al-Qur'an sebagai pegangan hidup umat Islam telah mengatur secara eksplisit tata cara atau kegiatan-kegiatan berbisnis, dan memandang bisnis sebagai sebuah pekerjaan yang menguntungkan dan menyenangkan, sehingga al-Quran sangat mendorong dan memotivasi umat Islam untuk melakukan transaksi bisnis dalam kehidupan mereka. ${ }^{2} \mathrm{Al}$ Quran mengakui legitimasi bisnis, dan juga memaparkan prinsip-prinsip dan petunjuk-petunjuk dalam masalah bisnis antar individu maupun kelompok. Al-Quran mengakui hak individu dan kelompok untuk memiliki dan memindahkan suatu kekayaan secara bebas dan tanpa paksaan. Al Quran mengakui otoritas deligatif terhadap harta yang dimiliki secara legal oleh seorang individu atau kelompok. Al Quran memberikan kemerdekaan penuh untuk melakukan transaksi apa saja, sesuai dengan yang dikehendaki dengan batas-batas yang ditentukan oleh Syari'ah. Kekayaan dianggap sebagai sesuatu yang tidak bisa diganggu gugat dan tindakan penggunaan harta orang lain dengan cara tidak halal atau tanpa izin dari pemilik yang sah merupakan hal yang dilarang. Oleh karena itu, penghormatan hak hidup, harta dan kehormatan merupakan kewajiban agama sebagaimana terungkap dalam Surah An Nisaa ayat 29. ${ }^{3}$

${ }^{2}$ Allah SWT telah menegaskan firman-Nya dalam Q.S. Al-Baqarah ayat 275. “...Allah telah menghalalkan jual beli dan mengharamkan riba.". 
Pengakuan al-Quran terhadap pemilikan harta benda, merupakan dasar legalitas seorang Muslim untuk mengambil keputusan yang berhubungan dengan harta miliknya, apakah dia akan menggunakan, menjual atau menukar harta miliknya dengan bentuk kekayaan yang lain. Al Quran memberikan kebebasan berbisnis secara sempurna, baik yang bersifat internal maupun eksternal. Pembatasan dalam hal keuangan dan kontrol pertukaran juga dibebaskan, karena hal itu menyangkut kebebasan para pelaku bisnis.

Krisis moneter di Indonesia pada tahun 1997 mengakibatkan krisis pula di sektor perbankan. Pada saat itu sejumlah bank ada yang dibekukan, dilikuidasi dan ada yang di take over oleh pemerintah, karena dinilai oleh pemerintah sebagai bank yang tidak sehat. Sebagai akibat pembekuan dan penglikuidasian sejumlah bank tersebut berakibat kepercayaan masyarakat terhadap lembaga perbankan menjadi berkurang. Pembekuan dan penglikuidasian sejumlah bank kala itu dinilai sangat merugikan berbagai pihak, tidak hanya karyawan bank yang merasa dirugikan karena harus di PHK, juga nasib nasabah penyimpan dana menjadi tidak jelas. Peraturan yang mengatur akibat likuidasi bank terhadap nasabah penyimpan dana pada saat itu seperti Peraturan Pemerintah No. 68 Tahun 1996 Tentang Ketentuan Dan Tatacara Pencabutan Ijin Usaha, Pembubaran dan Likuidasi Bank jo. SKBI No.30/Kep/Dir/1997 ternyata hanya menempatkan nasabah penyimpan dana pada posisi urutan ke-6 dalam prioritas pembayaran dari hasil penjualan aset bank yang terlikuidasi. Hal itu menunjukkan bahwa peraturan yang ada pada saat itu belum memberikan perlindungan hukum yang baik kepada nasabah penyimpan dana pada lembaga perbankan.

Berdasarkan Pasal 1 Undang-Undang No. 7 Tahun 1992 Tentang Perbankan yang telah diubah dengan UU No. 10 Tahun 1998 (selanjutnya disebut UU Perbankan), yang dimaksud bank adalah badan usaha yang menghimpun dana dari masyarakat dalam bentuk simpanan dan menyalurkannya kepada masyarakat dalam rangka meningkatkan taraf hidup rakyat banyak.

Pasal 3 UU Perbankan mengatakan bahwa fungsi utama perbankan Indonesia adalah sebagai penghimpun dan penyalur dana masyarakat. Pasal 4 UU Perbankan mengatakan bahwa tujuan perbankan Indonesia adalah menunjang pelaksanaan pembangunan nasional dalam rangka meningkatkan pemerataan, pertumbuhan ekonomi, dan stabilitas nasional ke arah peningkatan kesejahteraan rakyat banyak.

${ }^{3}$ Q.S. An-Nissa' 29 menegaskan, "Hai orang-orang yang beriman, janganlah kamu saling memakan harta sesamamu dengan jalan yang batil, kecuali dengan jalan perdagangan yang berlaku suka sama suka diantara kamu...". 
Jika dilihat fungsi dan tujuan perbankan Indonesia, maka peranan bank di Indonesia adalah sangat penting dalam menunjang pembangunan nasional, khususnya pembangunan ekonomi, dimana bank berfungsi sebagai lembaga intermediasi antara pihak penyimpan dana sebagai pihak yang surplus dana dengan pihak yang membutuhkan dana sebagai pihak yang minus dana. Jika pihak yang membutuhkan dana, memperoleh dana dari bank dan digunakan untuk kegiatan usaha yang produktif, dan menyerap tenaga kerja banyak, serta menghasilkan barang/jasa yang punya nilai lebih, maka niscaya tujuan sebagaimana yang disebutkan dalam Pasal 4 UU Perbankan tersebut akan terwujud.

Krisis moneter di Indonesia tahun 1997/1998 mengakibatkan kepercayaan masyarakat terhadap perbankan nasional menurun tajam. Untuk itu pemerintah mengeluarkan kebijakan untuk memberikan penjaminan terhadap seluruh kewajiban bank (blanket guarantee) merupakan suatu upaya menumbuhkan kembali kepercayaan masyarakat dan mendukung stabilitas sistem keuangan. Kebijakan tersebut dituangkan dalam Kep Pres No.26 Tahun 1998 tentang Jaminan Terhadap Kewajiban Bank Umum yang diubah dengan Kepres No.17 Tahun 2004 dan Kep Pres No.193 Tahun 1998 tentang Jaminan terhadap Bank Perkreditan Rakyat (BPR) Penjaminan pemerintah tersebut dilaksanakan oleh Menteri Keuangan.

Kebijakan blanket guarantee terbukti meningkatkan kepercayaan masyarakat terhadap perbankan, namun di sisi lain kebijakan tersebut menimbulkan distorsi baru yakni membebani keuangan negara dan menimbulkan moral hazard.

Oleh karena itu diperlukan pembentukan Lembaga Penjamin Simpanan (LPS) untuk mengganti fungsi Menteri Keuangan sebagai penjamin simpanan. LPS ini diperlukan untuk memberi rasa aman dan memberikan kepercayaan nasabah terhadap sistem dan institusi keuangan yang ada. Pada tanggal 22 September 2004 telah disahkan dan diundangkan UU No.24 Tahun 2004 tentang Lembaga Penjamin Simpanan (selanjutnya disebut UU LPS), yang mulai berlaku efektif pada tanggal 22 September 2005. LPS telah diresmikan oleh Menteri Keuangan Yusuf Anwar dan pemerintah telah mengangkat anggota Dewan Komisioner LPS melalui Kep Pres No.161/M/2005. Modal awal LPS 4 trilliun rupiah.

Dalam Pasal 4 UU LPS disebutkan fungsi LPS adalah: a. menjamin simpanan nasabah penyimpan; dan b. turut aktif dalam memelihara stabiltas sistem perbankan sesuai kewenangannya. Mengenai fungsi LPS untuk menjamin simpanan nasabah penyimpan, dijabarkan lebih lanjut dalam Pasal 8-20 UU LPS. Setiap bank yang melakukan kegiatan usaha di wilayah Negara Republik Indonesia wajib menjadi peserta Penjaminan, kecuali Badan Kredit Desa (Pasal 8). Peserta penjaminan antara lain wajib membayar kontribusi kepesertaan sebesar $0,1 \%$ dari modal sendiri bank, wajib membayar premi (Pasal 9). LPS hanya menjamin simpanan nasabah bank yang 
berbentuk giro, deposito, sertifikat deposito, tabungan, dan/atau bentuk lainnya yang dipersamakan dengan itu (Pasal 10). Nilai simpanan yang dijamin untuk setiap nasabah pada satu bank paling banyak Rp.100 juta, nilai simpanan yang dijamin dapat diubah apabila memenuhi salah satu atau lebih kriteria yang ditetapkan dalam UU LPS dan dikonsultasikan dengan DPR (Pasal 11).

Kehadiran UU LPS ternyata tidak sepenuhnya disambut dengan sukacita, beberapa pendapat ada yang bernada khawatir dan pesimis dengan kehadiran UU ini, seperti yang dikemukakan oleh Fahmi Achmad, bahwa pemerintah melalui LPS secara resmi hanya menjamin dana nasabah maksimum Rp.100 juta, artinya bagi nasabah yang simpanannya dibawah Rp.100 juta bisa merasa aman menyimpan uangnya di bank, tetapi bagaimana bagi nasabah yang simpanannya lebih dari Rp.100 juta? Dengan demikian jika ingin investasi, jangan taruh telur dalam satu keranjang. ${ }^{4}$

Dengan kata lain UU LPS belum sepenuhnya memberikan rasa aman kepada nasabah bank, karena penjaminannya terbatas.

Sementara itu A Deni Daniri mengatakan bahwa keberadaan LPS sangat rentan bagi perekonomian, karena dengan hanya modal Rp.4 trilliun dan perolehan premi $0,2 \%$ per tahun dari total dana pihak ketiga yang dijamin sebesar Rp.900 trilliun, posisi LPS amat mengkhawatirkan. Hal ini karena LPS didirikan oleh lembaga milik pemerintah, jika kemudian hari ada bank yang dirush atau dilikuidasi, maka harus ditalangi oleh lembaga tersebut, dan jika dana yang dirush atau bank yang dilikuidasi tersebut melebihi kapasitas modal LPS, maka pemerintah/rakyat harus menalangi lagi. Menurutnya fungsi dan peranan LPS tak ubahnya seperti BPPN jilid kedua, sehingga akan menimbulkan moral hazard yang besar dimasa yang akan datang. ${ }^{5}$

Namun demikian dari perspektif hukum keberadaan Lembaga Penjamin Simpanan telah menimbulkan berbagai permasalahan hukum, khususnya dalam upaya perlidungan hukum bagi nasabah penyimpan dana sehingga memerlukan kajian mendalam sesegera mungkin. Persoalan-persoalan tersebut dapat muncul terutama berkaitan dengan kedudukan nasabah dan prinsip-prinsip perlindungan hukum itu sendiri, seperti apakah perlindungan hukum LPS sudah mencerminkan aspek keadilan sebagai esensi dari perlindungan hukum. Sehingga hal ini merupakan tantangan bagi kalangan orang hukum. Sementara dalam konteks Hukum Islam

\footnotetext{
${ }^{4}$ Fahmi Ahmad, LPS Terbentuk Siapa Yang Diuntungkan, Bisniscom, 20 Oktober 2005.

${ }^{5}$ A Deni Daniri, Keberadaan LPS Sangat Rentan, Indonesiacom, 15 Nopember 2005.
} 
menyangkut bagaimana Hukum Islam merespon pengaturan ketentuan-ketentuan hukum yang berkaitan dengan kedudukan lembaga penjamin simpanan.

Dari uraian di atas isu hukum yang muncul; Pertama, bagaimanakah kedudukan LPS sebagai lembaga penjamin nasabah dalam sudut pandang UndangUndang Nomor 24 tahun 2004 dalam rangka perlindungan hukum terhadap nasabah penyimpan dana? Apakah dengan konsep perlindungan hukum tersebut nasabah penyimpan telah benar-benar mendapatkan perlindungan hukum? Kedua, bagaimanakah kedudukan LPS sebagai lembaga penjamin nasabah dalam sudut pandang Hukum Islam? Hal tersebut memerlukan penjelasan ataupun klarifikasi dari sudut Hukum Positif dan Hukum Islam. Konsekuensi dari tinjauan ini maka penelaahan yang dilakukan bercorak mendasar, komprehensif dan holistik.

\section{Lembaga Penjamin Simpanan (LPS) Menurut Undang-Undang Nomor 24 Tahun 2004}

\section{Kedudukan Hukum Nasabah Penyimpan Dana}

UU LPS memberikan pengertian nasabah penyimpan adalah nasabah penyimpan sebagaimana yang disebutkan dalam UU Perbankan, sedangkan UU Perbankan memberikan pengertian nasabah penyimpan adalah nasabah yang menempatkan dananya di bank dalam bentuk simpanan berdasarkan perjanjian bank dengan nasabah yang bersangkutan. Untuk lebih memperoleh kejelasan dari pengertian nasabah penyimpan dana kita perlu mengetahui hukum yang mengaturnya. Muhamad Djumhana ${ }^{6}$ memberi pengertian hukum perbankan adalah sekumpulan peraturan hukum yang mengatur kegiatan lembaga keuangan Bank yang meliputi segala aspek, dilihat dari segi esensi, dan eksistensinya, serta hubungan dengan bidang kehidupan yang lain. Munir Fuadi, ${ }^{7}$ hukum perbankan (banking law) merupakan seperangkat kaidah dalam bentuk peraturan perundangan, yurisprudensi, doktrin, dan lain-lain sumber hukum yang mengatur masalah-masalah perbankan sebagai lembaga, dan aspek kegiatan sehari-hari, rambu-rambu yang harus dipenuhi oleh suatu bank,

\footnotetext{
${ }^{6}$ Muhamad Djumhana, "Hukum Perbankan Di Indonesia", (Bandung: PT Citra Aditya Bakti, 1996), hal. 1.

${ }^{7}$ Munir Fuadi, "Hukum Perbankan Modern Buku Kesatu", (Bandung: PT Citra Aditya Bakti, 1999), hal. 14.
} 
perilaku petugas-petugasnya, hak dan kewajiban, tugas dan tanggung jawab para pihak yang tersangkut dengan bisnis perbankan, apa yang boleh dan tidak boleh dilakukan oleh bank, eksistensi perbankan, dan lain yang berkenaan dengan dunia perbankan. UU Perbankan memberi pengertian perbankan adalah segala sesuatu yang menyangkut tentang bank, mencakup kelembagaan, kegiatan usaha, serta cara dan proses dalam melaksanakan kegiatan usahanya, sehingga hukum perbankan dapat diartikan sekumpulan peraturan yang mengatur segala sesuatu yang menyangkut tentang bank, mencakup kelembagaan, kegiatan usaha serta cara dan proses dalam melaksanakan kegiatan usahanya. Ruang lingkup hukum perbankan tidak terbatas pada pengaturan hubungan perdata (hubungan antara orang perseorangan/badan hukum sebagai nasabah dengan bank) saja, tetapi hukum perbankan juga mengatur hubungan administrasi negara (hubungan antara bank dengan negara dalam hal bank memerlukan penetapan administrasi negara yang bersifat yuridis seperti perizinan untuk mendirikan dan menjalankan usaha bank), selain itu hukum perbankan juga mengatur mengenai sanksi pidana terhadap pelanggaran dan lain sebagainya. Dalam UU Perbankan disebutkan bahwa kegiatan usaha bank yang utama adalah menghimpun dana dari masyarakat dalam bentuk simpanan dan menyalurkannya kepada masyarakat dalam bentuk kredit dan/atau bentuk-bentuk lainnya dalam rangka meningkatkan taraf hidup rakyat banyak. Dalam melaksanakan kegiatan menghimpun dana dari masyarakat penyimpan dana dilakukan dengan perjanjian penyimpanan antara bank dengan nasabah penyimpan, bentuk simpanan dapat berupa giro, deposito berjangka, sertifikat deposito, tabungan dan/atau bentuk lainnya yang dipersamakan dengan itu. Dapat disimpulkan hubungan bank dengan nasabah penyimpan merupakan hubungan antara orang perseorangan yang merupakan lingkup hukum perdata (hubungan kontraktual), selain itu antara bank dengan nasabah penyimpan terdapat hubungan non kotraktual yang sering disebut dengan asas-asas khusus dari hubungan nasabah dengan bank. Asas khusus tersebut antara lain hubungan kepercayaan (fiducia relation), hubungan kerahasiaan (confidential relation), hubungan kehati-hatian (prudential relation), ${ }^{8}$ sedangkan hubungan nasabah penyimpan dana dengan LPS berdasarkan UU LPS akan dibahas dalam bab selanjutnya.

${ }^{8}$ Ibid, hal. 104. 


\section{Fungsi Perlindungan Hukum Terhadap Nasabah Penyimpan Dana Menurut UU LPS}

Konsideran UU LPS menyebutkan, bahwa salah satu pertimbangannya mengingat UU No. 7 Tahun 1992 tentang Perbankan sebagaimana yang diubah dengan UU No. 10 Tahun 1998, artinya UU Perbankan ini merupakan salah satu yang mendasari berlakunya UU LPS, karena memang dalam Pasal 37 B UU Perbankan dikatakan bahwa (1) Setiap bank wajib menjamin dana masyarakat yang disimpan pada bank yang bersangkutan. (2) Untuk menjamin simpanan masyarakat pada bank sebagaimana dimaksud dalam ayat (1) dibentuk Lembaga Penjamin Simpanan. (3) Lembaga Penjamin Simpanan sebagaimana dimaksud dalam ayat (2) berbentuk badan hukum Indonesia. (4) Ketentuan mengenai penjamin dana masyarakat dan Lembaga Penjamin Simpanan diatur lebih lanjut dengan Peraturan Pemerintah. Yang dimaksud oleh Pasal 37 B ayat (4) UU Perbankan bukan Peraturan Pemerintah melainkan UU No.24 Tahun 2004 tentang Lembaga Penjamin Simpanan (LPS).

Pasal 4 UU LPS mengatakan bahwa fungsi LPS adalah: a. menjamin simpanan nasabah. b. turut aktif dalam memelihara stablitas sistem perbankan sesuai dengan kewenangannya. Kemudian dalam penjelasan umumnya ditegaskan lagi bahwa fungsi LPS adalah menjamin simpanan nasabah bank dan melakukan penyelesaian atau penanganan Bank Gagal.

Untuk fungsi LPS yang pertama yaitu menjaminan simpanan nasabah bank dijabarkan lebih lanjut dalam Bab IV (pasal 8-20) UU LPS. Pasal 8 UU LPS mengatakan bahwa setiap bank yang melakukan kegiatan usaha di wilayah Negara RI wajib menjadi peserta Penjaminan. Pasal 10 UU LPS mengatakan bahwa LPS menjamin simpanan nasabah bank yang berbentuk giro, deposito, sertifikat deposito, tabungan, dan/atau bentuk lainnya yang dipersamakan dengan itu. Pasal 11 UU LPS mengatakan bahwa nilai simpanan yang dijamin untuk setiap nasabah pada suatu bank adalah Rp 100 juta. Nilai simpanan yang dijamin dapat diubah apabila terpenuhi salah satu atau lebih kriteria yang disebutkan dalam ayat (2), dan ketentuan lebih lanjut tentang hal ini akan diatur dengan Peraturan LPS. Pasal 12 mengatakan bahwa premi penjaminan dibayarkan 2 kali dalam satu tahun. Pasal 13 mengatakan premi setiap periode ditetapkan sama untuk untuk setiap bank sebesar $0,1 \%$ (satu perseribu) dari rata-rata saldo bulanan total simpanan dalam setiap periode. Selanjutnya Pasal 16 -20 UU LPS mengatur mengenai Pembayaran Klaim Penjaminan. Pasal 16 ayat (1) mengatakan bahwa LPS wajib membayar klaim Penjamin kepada nasabah kepada nasabah peyimpan dari bank yang dicabut ijin usahanya. Pasal 
18 mengatakan bahwa dalam hal nasabah penyimpan pada saat yang bersamaan mempunyai kewajiban kepada bank, maka pembayaran klaim penjaminan dilakukan setelah kewajiban nasabah penyimpan kepada bank terlebih dahulu diperhitungkan berdasarkan peraturan perundang-undangan. Pasal 19 ayat (1) mengatakan bahwa klaim penjaminan dinyatakan tidak layak dibayar apabila berdasarkan hasil rekonsiliasi dan/atau verifikasi: a. data simpanan nasabah dimaksud tidak tercatat pada bank; b. nasabah penyimpan merupakan pihak yang diuntungkan secara tidak wajar, dan/atau; c. nasabah penyimpan merupakan pihak yang menyebabkan keadaan bank menjadi tidak sehat. Pasal 20 ayat (1) mengatakan dalam hal nasabah penyimpan sebagaimana dimaksud dalam Pasal 19 ayat (1) merasa dirugikan, maka nasabah dimaksud dapat mengajukan a. keberatan kepada LPS yang didukung dengan bukti nyata dan jelas; atau b. melakukan upaya hukum melalui pengadilan.

Pertanyaanya adalah apakah konsep perlindungan hukum terhadap nasabah penyimpan dana yang diberikan oleh UU LPS, tersebut sudah memenuhi kriteria perlindungan hukum? Terlebih dahulu harus dijelaskan mengenai hubungan hukum antara LPS dengan nasabah penyimpan dana, apakah hubungan hukum itu bersifat perdata atau bersifat publik. Hal ini dikaitkan dengan konsep perlindungan hukum yang berbeda antara hukum yang mengatur hubungan hukum perdata (hukum perdata) dengan hukum yang mengatur hubungan hukum publik (hukum publik) yang telah dijelaskan pada bab sebelumnya, dan untuk itupun terlebih dahulu harus dijelaskan apakah perbedaan hukum perdata dengan hukum publik.

Dalam bukunya Mr. N.E.Algra, Mr. K.Van Duyvendijk, J.C.T Simorangkir, H. Boerhanoeddin Soetan Batoeah ${ }^{9}$ dapat disimpulkan perbedaan antara hukum privat/perdata dan hukum publik:

(1).Hukum publik mengatur organisasi negara (hukum tata negara) dan hubungan antara penguasa dan warga negara (hukum administrasi, hukum pidana). Yang terakhir hukum publik mengatur campur tangan pemerintah yang aktif dalam hidup bermasyarakat. Dalam hukum publik, sepanjang tidak mengenai lembaga negara -pengawasan adalah bahwa hubungan hukum itu ditetapkan secara sepihak oleh pemerintah seperti penetapan pajak, pemberian ijin membangun.

${ }^{9}$ Mr. N.E. Algra, Mr. K. Van Duyvendijk, J.C.T Simorangkir, H. Boerhanoeddin Soetan Batoeah, "Pengantar Ilmu Hukum", (Jakarta: Bina Cipta, 1983), hal. 163 - 173. 
Hukum privat mengatur hubungan antar warga negara yang satu satu sama lain. Yang khas bagi hukum privat adalah pangkal tolak, bahwa pada prinsipnya warga negara boleh mengatur sendiri menurut pandangannya hubungan satu sama lain. Asaa pokok otonomi warga negara ini antara lain ialah milik pribadi, kebebasan membuat testament (dalam batas tertentu, seseorang membuat sendiri warisannya), kebebasan membuat kontrak.

(2). Dalam hukum publik hal mempertahankan haknya pada umumnya di tangan pemerintah. Misal pembongkaran bangunan tanpa ijin oleh kotapraja, tuntutan hukum seorang tersangka ditangan jaksa.

Dalam hukum privat hal mempertahankan haknya itu di tangan para warga negara itu sendiri, dalam hal mana mereka memang terikat pada prosedur yang telah ditetapkan.

(3). Tujuan hukum publik adalah kepentingan umum.

Tujuan hukum privat adalah kepentingan perorangan dari warga negara.. Pembedaan ini memang belum diperoleh kejelasan, karena 1) pengertian kepentingan umum adalah suatu pengertian yang samar 2) pengertian kepentingan umum dan kepentingan pribadi sering tidak dapat dibedakan dengan jelas satu sama lain.

Kini orang sulit untuk membedakan berbagai hukum baru untuk dimasukkan dalam bagan (schema) hukum publik atau hukum privat. Contoh ialah hukum kerja, yang terdiri baik hukum privat dan hukum publik. Batas antara hukum publik dan hukum privat dalam prakteknya makin lama makin sulit untuk menegaskannya. Ini berarti, bahwa kini makin kurang dapat diadakan suatu pembedaan teoritis yang tajam dengan ukuran yang jelas. Paling tinggi dapat dibedakan bentuk hukum publik yang khas dan bentuk hukum privat yang khas pula, tetapi tidak mungkin lagi mengadakan pembagian yang cocok (pas) sebagaimana dulu pernah diadakan dalam hukum publik dan hukum privat. Pembedaan apakah hukum publik, privat atau campuran mempunyai arti penting dalam penyelesaian persoalan yuridis, hubungan apa yang dilihat antara hukum publik dan hukum privat dan konsekuensi apa yang dapat ditarik darinya.

Di depan telah dijelaskan bahwa ruang lingkup hukum perbankan tidak terbatas pada pengaturan hubungan perdata (hubungan antara orang perseorangan/badan hukum sebagai nasabah dengan bank) saja, tetapi hukum perbankan juga mengatur hubungan administrasi negara (hubungan antara bank dengan negara dalam hal bank memerlukan penetapan administrasi negara yang bersifat yuridis seperti perizinan 
untuk mendirikan dan menjalankan usaha bank), selain itu hukum perbankan juga mengatur mengenai sanksi pidana terhadap pelanggaran dsb, dan UU Perbankan (yang merupakan hukum perbankan) ini sebagai salah satu yang mendasari berlakunya UU LPS.

Berdasarkan ketentuan Pasal 2 ayat (2), LPS adalah badan hukum, dikaitkan dengan ketentuan Pasal 2 ayat (3) yaitu LPS bertanggung jawab kepada Presiden, LPS adalah badan hukum publik. Suatu lembaga adalah badan TUN (Tata Usaha Negara) apabila badan tersebut melaksanakan wewenang publik. Dengan karakter wewenang tersebut, tindakan badan TUN adalah tindakan hukum publik. Tindakan hukum publik dalam bentuk peraturan dan keputusan TUN. Berdasarkan UU LPS, LPS berwenang membuat peraturan a.1 . Pasal 16 ayat (8), Pasal 19 ayat (2), Pasal 24 ayat (2), Pasal 33 ayat (2), Pasal 41 ayat (3) dikaitkan dengan ketentuan Pasal 7 ayat (4) UU No.10 Tahun 2004 tentang Tata Cara Pembentukan Peraturan Perundangundangan, peraturan LPS adalah peraturan perundang-undangan (kategori regulasi). Dalam Pasal 6 ayat (1) ditetapkan wewenang LPS untuk menetapkan premi (a); menetapkan dan memungut kontribusi (b); menunjuk dan menguasakan dan/atau menugaskan pihak lain (g), menjatuhkan sanksi administrative (i). Dalam Pasal 22 ayat (2) ditetapkan wewenang LPS untuk melakukan penyelamatan atau tidak melakukan penyelamatan Bank Gagal. Dalam Pasal 43, LPS berwenang memutuskan pembubaran badan hukum bank. Figur tindakan LPS tersebut di atas jelas merupakan keputusan TUN. Dalam kaitan dengan UU No.5 tahun 1996 tentang PTUN jo UU No.9 Tahun 2004, perlu dikaji kemungkinan Keputusan TUN yang diterbitkan LPS termasuk kategori ketentuan Pasal 2 dalam huruf a yaitu Keputusan TUN yang merupakan perbuatan hukum perdata. Lazimnya Keputusan tersebut dikenal sebagai Keputusan yang melebur dalam tindakan hukum perdata. ${ }^{10}$

Dalam Pasal 5 ayat (1) UU LPS, LPS mempunyai tugas merumuskan dan menetapkan kebijakan pelaksanaan penjaminan simpanan; dan melaksanakan penjaminan simpanan. Pasal 6 ayat (1) huruf a, f, UU LPS, LPS mempunyai wewenang menetapkan dan memungut premi penjaminan; menetapkan syarat, tata cara, dan ketentuan pembayaran klaim, dikaitkan dengan Pasal 10 UU LPS, LPS menjamin simpanan nasabah bank yang berbentuk giro, deposito, sertifikat deposito, tabungan, dan/atau bentuk lainnya yang dipersamakan dengan itu. Pasal 11 UU LPS menjamin simpanan nasabah pada suatu bank paling banyak seratus juta. Dihubungkan dengan pendapat diatas maka perbuatan LPS merupakan Keputusan

${ }^{10}$ Philipus M Hadjon, Tanggung Gugat Lembaga Penjamin Simpanan Sebagai badan Hukum Menurut Undang-Undang No.24 Tahun 2004, Seminar Nasional LPS Sebagai Wahanan Perlindungan Dana Simpanan Nasabah, Fakultas Hukum Unair, Surabaya, 1 Juli 2006. 
TUN yang berarti perbuatan LPS adalah perbuatan hukum publik, sehingga dapat disimpulkan hubungan hukum antara LPS dengan nasabah penyimpan dana merupakan hubungan hukum publik. Selain itu jika dihubungkan dengan ciri-ciri hukum publik memenuhi beberapa ciri hukum publik yaitu mengatur hubungan penguasa (LPS sebagai badan hukum publik yang melakukan perbuatan hukum publik/keputusan TUN), tujuannya untuk mengatur kepentingan umum (tujuan perbankan Indonesia adalah menunjang pelaksanaan pembangunan nasional dalam rangka meningkatkan pemerataan, pertumbuhan ekonomi, dan stabilitas nasional ke arah peningkatan kesejahteraan rakyat banyak dan UU LPS bertujuan untuk menjaga kepercayaan masyarakat terhadap lembaga perbankan dengan dibentuk LPS).

Selanjutnya jika Pasal 5 ayat (1) dan Pasal 6 ayat (1) huruf a, f UU LPS dihubungkan dengan Pasal 18 UU LPS mengatakan bahwa dalam hal nasabah penyimpan pada saat yang bersamaan mempunyai kewajiban kepada bank, maka pembayaran klaim penjaminan dilakukan setelah kewajiban nasabah penyimpan kepada bank terlebih dahulu diperhitungkan berdasarkan peraturan perundangundangan. Pasal 19 ayat (1) mengatakan bahwa klaim penjaminan dinyatakan tidak layak dibayar apabila berdasarkan hasil rekonsiliasi dan/atau verifikasi: a. data simpanan nasabah dimaksud tidak tercatat pada bank; b. nasabah penyimpan merupakan pihak yang diuntungkan secara tidak wajar, dan/atau; c. nasabah penyimpan merupakan pihak yang menyebabkan keadaan bank menjadi tidak sehat. Pasal 20 ayat (1) mengatakan dalam hal nasabah penyimpan sebagaimana dimaksud dalam Pasal 19 ayat (1) merasa dirugikan, maka nasabah dimaksud dapat mengajukan a. keberatan kepada LPS yang didukung dengan bukti nyata dan jelas; atau b. melakukan upaya hukum melalui pengadilan. Pasal 18, Pasal 19 dihubungkan dengan Pasal 20 UU LPS merupakan ketentuan yang mempunyai ciri-ciri hukum perdata yaitu mengatur hubungan antar warga negara yang satu satu sama lain (aturan tentang kompensasi utang antara bank dengan nasabah penyimpan dana), hal mempertahankan haknya itu di tangan para warga negara itu sendiri, dalam hal mana mereka memang terikat pada prosedur yang telah ditetapkan (nasabah yang dirugikan dapat mengajukan keberatan ke LPS atau Pengadilan), tujuan hukum privat adalah kepentingan perorangan (mengatur kepentingan nasabah). Dengan demikian wewenang LPS dihubungankan Pasal 18,19 dan 20 UU LPS merupakan keputusan yang melebur dalam tindakan hukum perdata. Sehingga dapat disimpulkan bahwa UU LPS didalamnya mengatur hubungan hukum publik dan mengatur hubungan hukum perdata. Konsisten dengan hal itu, maka konsep perlindungan hukum terhadap nasabah penyimpan dana dalam UU LPS adalah perlindungan hukumnya sesuai dengan ketentuan yang mengatur hubungan hukum publik, dimana nasabah penyimpan dana memperoleh hak/perlindungan sesuai yang diberikan oleh 
negara/badan hukum publik/LPS (keadilan distributif) dan sesuai dengan ketentuan yang mengatur hubungan hukum perdata, dimana nasabah penyimpan dana memperoleh hak/perlindungan sama banyaknya (keadilan commutatif).

Pertanyaan selanjutnya adalah apakah konsep perlindungan hukum terhadap nasabah penyimpan dana yang diberikan oleh UU LPS telah benar-benar memberikan perlindungan hukum? Akan diuraikan sebagai berikut, bahwa di depan telah dijelaskan bahwa UU LPS di dalamnya mengatur hubungan hukum publik dan juga mengatur hubungan hukum perdata, maka hubungan nasabah penyimpan dana dengan LPS pun dilingkupi dalam kedua hukum tersebut, sedangkan hubungan antara bank dengan nasabah penyimpan dana merupakan hubungan perdata sebagaimana telah dijelaskan pada bab sebelumnya. Selain itu hubungan antara bank dengan nasabah merupakan hubungan kepercayaan, hal ini terjadi karena bank memiliki status yang unik ditengah masyarakat - selain bank sebagai sandaran suatu kepercayaan ia juga menempati posisi khusus sebagai tempat yang aman. ${ }^{11}$ Dengan karakteristik yang demikian, maka bank memiliki kewajiban untuk mengungkapkan ( a duty to disclose) seluruh fakta material kepada nasabahnya, apabila bank memiliki pengetahuan yang mungkin sangat penting bagi nasabahnya. Pasal 29 ayat (4) UU Perbankan mengatakan bahwa untuk kepentingan nasabah, bank wajib menyediakan informasi mengenai kemungkinan timbulnya risiko dengan sehubungan dengan transaksi nasabah yang dilakukan melalui bank. Ini menunjukkan bahwa hubungan antara bank dengan nasabah mempunyai hubungan fiducia, sehingga bank mempunyai kewajiban a duty to disclos. Prinsip fiducia/kepercayaan memberikan suatu landasan untuk meminta pertanggungjawaban dan membayar ganti rugi atas ganti kerugian yang disebabkan bukan karena wanprestasi. ${ }^{12}$ Dalam hubungan hukum perdata, nasabah yang dirugikan oleh perbuatan LPS mempunyai hak/perlindungan untuk mengajukan keberatan keberatan kepada LPS atau melakukan upaya hukum ke Pengadilan (Pasal 20 UU LPS). Dalam hubungan fiducia/kepercayaan antara bank dengan nasabah, nasabah mendapat perlindungan hukum sebagaimana yang disebutkan dalam Pasal 92 - 94 UU LPS. Dalam hubungan hukum publik antara LPS dengan nasabah penyimpan dana, hubungan

${ }^{11}$ Edward L. Symon, Jr., dalam Zulkarnain Sitompul, Dasar Filosofi Keberadaan Lembaga Penjamin Simpanan, Seminar Nasional LPS Sebagai Wahanan Perlindungan Hukum Dana Simpanan Nasabah, Fakultas Hukum Unairm Surabaya, 1 Juli 2006, hal. 1.

${ }^{12}$ Zulkarnain Sitompul, Dasar Filosofi Keberadaan Lembaga Penjamin Simpanan, Seminar Nasional LPS Sebagai Wahanan Perlindungan Hukum Dana Simpanan Nasabah, Fakultas Hukum Unairm Surabaya, 1 Juli 2006, hal. 3. 
hukum publik antara LPS dengan bank, sebagai mana diuraikan di depan, UU LPS rupanya belum memberikan hak/perlindungannya. Dengan demikian dapat disimpulkan bahwa nasabah penyimpan dana dalam konsep perlindungan hukum menurut UU LPS belum benar-benar mendapatkan perlindungan hukum, khususnya dalam hubungan hukum publik antara LPS dengan nasabah penyimpan dana. Konsisten dengan kesimpulan tersebut, maka perlu amandemen UU LPS untuk ditambahkan ketentuan yang mengatur hak nasabah penyimpan dana, hak bank atas perbuatan hukum publik LPS kepadanya.

\section{Lembaga Penjamin Simpanan Menurut Hukum Islam}

Kegiatan ekonomi merupakan salah satu dari aspek Mu'âmalah dari sistem Islam, sehingga kaidah fiqih yang digunakan dalam mengidentifikasi transaksitransaksi ekonomi juga menggunakan kaidah fiqih Mu'âmalah. Kaidah fiqih Mu'âmalah adalah "al-ashlu fì al-muâ 'malati al-ibâhah hattâ yadullu ad-dalîilu'ala tahrimiha" (hukum asal dalam urusan Mu'âmalah adalah boleh, kecuali ada dalil yang mengharamkannya). Ini berarti bahwa semua hal yang berhubungan dengan Mu'âmalah yang tidak ada ketentuan baik larangan maupun anjuran yang ada di dalam dalil Islam (al-Qur'an maupun al-Hadîst), maka hal tersebut adalah diperbolehkan dalam Islam.

Kaidah fiqih dalam Mu'âmalah di atas memberikan arti bahwa dalam kegiatan Mu'âmalah yang notabene urusan ke-dunia-an, manusia diberikan kebebasan sebebasbebasnya untuk melakukan apa saja yang bisa memberikan manfaat kepada dirinya sendiri, sesamanya dan lingkungannya, selama hal tersebut tidak ada ketentuan yang melarangnya. Kaidah ini didasarkan pada Hadîst Rasulullah yang berbunyi: "antum a'lamu bi 'umurid dunyâkum" (kamu lebih tahu atas urusan duniamu). Bahwa dalam urusan kehidupan dunia yang penuh dengan perubahan atas ruang dan waktu, Islam memberikan kebebasan mutlak kepada manusia untuk menentukan jalan hidupnya, tanpa memberikan aturan-aturan kaku yang bersifat dogmatis. Hal ini memberikan dampak bahwa Islam menjunjung tinggi asas kreativitas pada umatnya untuk bisa mengembangkan potensinya dalam mengelola kehidupan ini, khususnya berkenaan dengan fungsi manusia sebagai khalifah Allah di bumi.

Efek yang timbul dari kaidah fiqih Mu'âmalah di atas adalah adanya ruang lingkup yang sangat luas dalam penetapan hukum-hukum Mu'âmalah, termasuk juga hukum ekonomi. Ini berarti suatu transaksi baru yang muncul dalam fenomena kontemporer yang dalam sejarah Islam belum ada/dikenal, maka transaksi tersebut 
"dianggap" diperbolehkan, selama transaksi tersebut tidak melanggar prinsip-prinsip yang dilarang dalam Islam.

Salah satu fenomena mu'amalah dalam bidang ekonomi adalah Lembaga Penjamian Simpanan. Keberadaan lembaga ini mulai marak sekitar tahun 1997, di antaranya likuidasi 16 bank yang diikuti dengan krisis moneter dan perbankan pada tahun 1998. Akibat krisis ini telah mengakibatkan tingkat kepercayaan masyarakat pada sistem perbankan di Indonesia menurun, sehingga terjadi penarikan dana masyarakat dari sistem perbankan (bank runs) dalam jumlah yang sangat signifikan.

Dalam konteks hukum Islam, istilah Lembaga Penjamin Simpanan (LPS) tidak dikenal, meski demikian dalam lalu lintas perekonomian Islam dikenal lembaga yang memiliki sebagian dari tugas dan fungsi sebagaimaa LPS, lembaga tersebut adalah Baitul Mal atau dewasa ini lebih dikenal dengan istilah Baitul Mal wat Tamwil (BMT) ${ }^{13}$ Baitul Mal merupakan salah satu lembaga dalam negara Islam (Khilafah Islamiyah) yang tugas utamanya adalah mengelola segala pemasukan dan pengeluaran negara. ${ }^{14}$ Baitul Mal merupakan lembaga keuangan negara yang bertugas menerima, menyimpan, dan mendistribuslkan uang negara sesuai ketentuan syariat. Baitul Mal dapat disamakan dengan kas negara atau lembaga pejamian simpanan yang ada dewasa ini. ${ }^{15}$

Secara historis, fungsi dan eksistensi Baitul Mal secara jelas telah banyak diungkapkan baik pada masa Rasulullah SAW maupun pada masa kekhalifahan setelah Beliau wafat. Namun secara konkrit pelembagaan Baitul Mal baru dilakukan pada masa Umar Bin Khattab, ketika kebijakan pendistribusian dana yang terkumpul mengalami perubahan. Lembaga Baitul Mal itu berpusat di ibukota Madinah dan memiliki cabang di propinsi-propinsi wilayah Islam. ${ }^{16}$

Eksistensi lembaga Baitul Mal pada awalnya merupakan konsekwensi profesionalitas manajemen yang dilakukan pengelola zakat (amil). Namun ia juga merefleksikan ruang lingkup Islam, dimana Islam didefinisikan juga sebagai agama

13 Farid Ma'ruf, "Baitul Mal, Tinjauan Historis dan Konsep Idealnya", http://msiuii.net/baca.asp?katagori=rubrik\&menu=ekonomi\&baca=artikel\&id=75, diakses 1 Desember 2010 .

${ }^{14}$ Abdul Qadim Zallum, "Al Amwal Fi Daulah Al Khilafah", Cetakan I, (Beirut: Darul âI lmi Lil Malayin, 1983), hal. 10.

${ }^{15}$ Abdul Aziz Dahlan, et.al., "Ensiklopedi Hukum Islam", Cetakan II, (Jakarta: PT Ichtiar Baru van Hoeve, 1999), hal. 29. 2010.

${ }^{16}<$ http://abiaqsa.blogspot.com/baitul-mal-dalam-keuangan-publik.html $>$, diakses 1 Desember 
dan pemerintahan, qur'an dan kekuasaan, sehingga Baitul Mal menjadi salah satu komponen yang menjalankan fungsi-fungsi pemerintahan dan kekuasaan dari negara. ${ }^{17}$ Jadi ketika juga negara harus mengelola penerimaan-penerimaan negara baik yang diatur oleh syariah maupun yang didapat berdasarkan kondisi pada saat itu, negara membutuhkan lembaga yang menghimpun, mengelola dan mendistribusikan akumulasi dana negara tersebut untuk kepentingan negara, baik penggunaan yang memang diatur oleh syariah atau juga yang merupakan prioritas pembangunan ketika itu.

\section{Pengertian Baitul Mal wat Tamwil (BMT)}

Baitul Mal berasal dari bahasa Arab bait yang berarti rumah, dan al-mal yang berarti harta. Jadi secara etimologis (ma'na lughawi) Baitul Mal berarti rumah untuk mengumpulkan atau menyimpan harta. ${ }^{18}$

Adapun secara terminologis (ma'na ishtilahi), sebagaimana uraian Abdul Qadim Zallum ${ }^{19}$ dalam kitabnya Al Amwaal Fi Daulah Al Khilafah, Baitul Mal adalah suatu lembaga atau pihak (Arab: al jihat) yang mempunyai tugas khusus menangani segala harta umat, baik berupa pendapatan maupun pengeluaran negara. Jadi setiap harta baik berupa tanah, bangunan, barang tambang, uang, komoditas perdagangan, maupun harta benda lainnya di mana kaum muslimin berhak memilikinya sesuai hukum syara' dan tidak ditentukan individu pemiliknya $3 / 4$ walaupun telah tertentu pihak yang berhak menerimanya $3 / 4$ maka harta tersebut menjadi hak Baitul Mal, yakni sudah dianggap sebagai pemasukan bagi Baitul Mal. Secara hukum, harta-harta itu adalah hak Baitul Mal, baik yang sudah benar-benar masuk ke dalam tempat penyimpanan Baitul Mal maupun yang belum.

Demikian pula setiap harta yang wajib dikeluarkan untuk orang-orang yang berhak menerimanya, atau untuk merealisasikan kemaslahatan kaum muslimin, atau untuk biaya penyebarluasan dakwah, adalah harta yang dicatat sebagai pengeluaran Baitul Mal, baik telah dikeluarkan secara nyata maupun yang masih berada dalam tempat penyimpanan Baitul Mal.

${ }^{17}$ Yusuf Qardhawy, "Hukum Zakat”, (Jakarta: Pustaka Litera Antar Nusa, 1988), hal. 743.

${ }^{18}$ Abdul Aziz Dahlan, Op. Cit., hal. 18.

${ }^{19}$ Abdul Qadim Zallum, Op. Cit., hal. 120. 
Dengan demikian, Baitul Mal dengan makna seperti ini mempunyai pengertian sebagai sebuah lembaga atau pihak (al-jihat) yang menangani harta negara, baik pendapatan maupun pengeluaran.

Namun demikian, Baitul Mal dapat juga diartikan secara fisik sebagai tempat (al-makan) untuk menyimpan dan mengelola segala macam harta yang menjadi pendapatan negara. ${ }^{20}$

Baitul Mal dalam pengertian ini, telah dipraktekkan dalam sejạrah Islam sejak masa Rasulullah, diteruskan oleh para khalifah sesudahnya, yaitu masa Abu Bakar, Umar bin Khaththab, Utsman bin Affan, Ali Bin Abi Thalib, dan khalifah-khalifah berikutnya, hingga kehancuran Khilafah di Turki tahun 1924.

Sumber-sumber pendapatan Baitul Mal adalah fai', ghanimah/anfal, kharaj, jizyah, pemasukan dari harta milik umum, pemasukan dari harta milik negara, usyuur, khumus dari rikaz, tambang, serta harta zakat. Sedang pengelolaannya didasarkan pada 6 (enam) kategori harta, yaitu: (1) harta zakat, (2) harta untuk menanggulangi terjadinya kekurangan dan untuk melaksanakan kewajiban jihad, (3) harta sebagai suatu pengganti/kompensasi (badal/ujrah), seperti gaji pegawai negeri, (4) harta untuk kemaslahatan secara umum yang merupakan keharusan, (5) harta untuk kemaslahatan secara umum yang tidak merupakan keharusan, seperti simpanan dari nasabah bank; dan (6) harta untuk menangani kondisi darurat, semisal bencana alam.

\section{Sumber Dana dan Prinsip Manajemen Baitul Mal wat Tamwil (BMT)}

Dalam konteks sejarah, Baitul Mal khususnya yang berkenaan dengan tata organisasi dan administrasinya, dikenal istilah Diwan. Diwan adalah tempat di mana para penulis/sekretaris Baitul Mal berada dan tempat untuk menyimpan arsip-arsip. Istilah Diwan kadang juga dipakai dalam arti arsip-arsip itu sendiri, karena memang terdapat saling keterkaitan antara kedua makna bagi kata Diwan ini. Ringkasnya, Diwan dapat berarti kantor Baitul Mal, atau arsip Baitul Mal. ${ }^{21}$ Pada perkembangannya, Diwan dikelompokkan menjadi 2 (dua) menurut periodisasinya, yaitu: Pertama, Diwan-Diwan Baitul Mal Yang Paling Awal Terbentuk. Pembentukan diwan-diwan Baitul Mal yang pertama kali, ini dikhususkan sebagai tempat untuk menyimpan arsip-arsipnya, terjadi pada masa kekhilafahan Umar bin Al Khaththab, yaitu pada tahun 20 Hijriyah.

\footnotetext{
${ }^{20}$ Ibid.

${ }^{21}$ Ibid., hal. 123.
} 
Kedua, Diwan-Diwan Baitul Mal Yang Ada Kemudian. Jika yang diuraikan sebelumnya adalah Diwan (dalam arti arsip) yang pertama kali ada, yaitu Diwan untuk pemberian harta dan angkatan bersenjata (Diwan Al 'Atha' wal Jund). Adapun Diwan untuk pemasukan (kharaj, jizyah) dan pemungutan harta (Diwan Al Istifa ' wa Jibayatul Amwal), baru dikenal setelah periode kemudian.

Pada masa Umar bin Abdul Azis, dalam oparasionalnya institusi Baitul Mal dibagi menjadi beberapa departemen. Pembagian departemen dilakukan berdasarkan pos-pos penerimaan yang dimiliki oleh Baitul Mal sebagai bendahara negara. Sehingga departemen yang menangani zakat berbeda dengan yang mengelola khums, Jizyah, Kharaj dan seterusnya. ${ }^{22}$

Yusuf Qardhawy ${ }^{23}$ membagi baitul mal menjadi empat bagian (divisi) kerja berdasarkan pos penerimaannya, merujuk pada aplikasi masa Islam klasik:

1) Departemen khusus untuk sedekah (zakat);

2) Departemen khusus untuk menyimpan pajak dan upeti;

3) Departemen khusus untuk ghanimah dan rikaz;

4) Departemen khusus untuk harta yang tidak diketahui warisnya atau yang terputus hak warisnya (misalnya karena pembunuhan).

Hal ini sebenarnya juga telah diungkapkan pula oleh Ibnu Taimiyah, ${ }^{24}$ beliau mengungkapkan bahwa dalam adminstrasi keuangan Negara, dalam Baitul Mal telah dibentuk beberapa departemen yang dikenal dengan Diwan (dewan). Dewan-dewan tersebut diantaranya:

1) Diwan al Rawatib yang berfungsi mengadministrasikan gaji dan honor bagi pegawai negeri dan tentara;

2) Diwan al Jawali wal Mawarits al Hasyriyah yang berfungsi mengelola poll taxes (jizyah) dan harta tanpa ahli waris;

3) Diwan al Kharaj yang berfungsi untuk memungut kharaj;

4) Diwan al Hilali yang berfungsi mengkoleksi pajak bulanan, ${ }^{25}$

${ }^{22}$ Yusuf Qardhawy, Loc. Cit.

${ }^{23}$ Ibid.

24 Abdul Azim Islahi, "Economic Concepts of Ibn Taimiyah, The Islamic Foundation", (Leicester - UK, 1996/1417 H), hal. 204. 
Lalu bagaimana kedudukan BMT, dalam konteks perekonomian Islam modern, terutama berkaitan dengan sistem manajemen sebagai lembaga penjamin? Untuk membahas hal tersebut, berikut akan dilakukan analisis terhadap sumber dana dan prinsip pengelolaan BMT.

\section{Sumber Dana}

Syaikh Taqiyyuddin An Nabhani dalam kitabnya An Nizham Al Iqtishadi fi Al Islam 1990 telah menjelaskan sumber-sumber pemasukan bagi Baitul Mal dan kaidah-kaidah pengelolaan hartanya. Sumber-sumber tetap bagi Baitul Mal menurutnya adalah: fai', ghanimah/anfal, kharaj, jizyah, pemasukan dari harta milik umum, pemasukan dari harta milik negara, usyuur, khumus dari rikaz, tambang, serta harta zakat. ${ }^{26}$

Hanya saja, harta zakat diletakkan pada kas khusus Baitul Mal, dan tidak diberikan selain untuk delapan ashnaf (kelompok) yang telah disebutkan di dalam Al Qur'an. Tidak sedikit pun dari harta zakat tersebut boleh diberikan kepada selain delapan ashnaf tersebut, baik untuk urusan negara, maupun urusan umat.

Imam (Khalifah) boleh saja memberikan harta zakat tersebut berdasarkan pendapat dan ijtihadnya kepada siapa saja dari kalangan delapan ashnaf tersebut. Imam (Khalifah) juga berhak untuk memberikan harta tersebut kepada satu ashnaf atau lebih, atau membagikannya kepada mereka semuanya. ${ }^{27}$ Begitu pula pemasukan harta dari hak milik umum. Harta itu diletakkan pada Diwan khusus Baitul Mal, dan tidak boleh dicampuradukkan dengan yang lain.

${ }^{25}$ Perlu dipahami bahwa penggunaan kata pajak terkadang misleading karena literature ekonomi Islam atau sejarah Islam banyak menyebutkan pungutan yang dibenarkan atau dianjurkan oleh syariat seperti zakat, kharaj, ushr dan jizyah seringkali diwakili dengan istilah pajak. Padahal dalam Islam juga diketahui bahwa dalam keadaan normal pajak yang biasa dikenal dalam dunia konvensional tidak dianjurkan untuk diberlakukan. Untuk itu diperlukan ketelitian dari setiap pembaca ekonomi dan sejarah Islam dalam memahami konteks pembahasan pajak dalam berbagai jenis literature. Lihat, >http://1.bp.blogspot.com/taMajVQWOio/RudYVH1HzYI/AAAAAAAAACo/ n9ZZ3 QyEZA/s1600-h/public+finance.JPG/baitul-mal-dalam-keuangan-publik.html>， diakses 1 Desember 2010.

${ }^{26}$ Taqiyyuddin An Nabhani, “An Nizham Al Iqtishadi Fi Al Islam”, Cetakan IV, (Beirut: Darul Ummah, 1990), hal. 135.

${ }^{27}$ Ibid. 
Sebab harta tersebut menjadi hak milik seluruh kaum muslimin, yang diberikan oleh Khalifah sesuai dengan kemaslahatan kaum muslimin yang menjadi pandangan dan ijtihadnya berdasarkan hukum-hukum syara'.

Sedangkan harta-harta yang lain, yang merupakan hak Baitul Mal, diletakkan secara bercampur pada Baitul Mal dengan harta yang lain, serta dibelanjakan untuk urusan negara dan urusan umat, juga delapan ashnaf, dan apa saja yang penting menurut pandangan negara.

Apabila harta-harta ini cukup untuk memenuhi kebutuhan-kebutuhan rakyat, maka cukuplah dengan harta tersebut. Apabila tidak, maka negara berhak mewajibkan pajak (dharibah) kepada seluruh kaum muslimin, untuk menunaikan tuntutan dari pelayanan urusan umat. ${ }^{28}$

Yang juga termasuk dalam kategori sumber pemasukan yang diletakkan di dalam Baitul Mal dan dibelanjakan untuk kepentingan rakyat, adalah harta yang diperoleh oleh seorang 'asyir dari kafir harbi dan mu'ahad (disebut dengan istilah usyuur), harta-harta yang diperoleh dari hak milik umum atau hak milik negara, dan harta-harta waris dari orang yang tidak mempunyai ahli waris.

Apabila hak-hak Baitul Mal tersebut lebih untuk membayar tanggungannya, misalnya harta yang ada melebihi belanja yang dituntut dari Baitul Mal, maka harus diteliti terlebih dahulu: Apabila kelebihan tersebut berasal dari harta fai', maka kelebihan tersebut diberikan kepada rakyat dalam bentuk pemberian. Apabila kelebihan tersebut berasal dari harta jizyah dan kharaj, Baitul Mal akan menahan harta tersebut untuk disalurkan pada kejadian-kejadian yang menimpa kaum muslimin, dan Baitul Mal tidak akan membebaskan jizyah dan kharaj tersebut dari orang yang wajib membayarnya. Sebab, hukum syara' mewajibkan jizyah dari orang yang mampu, dan mewajibkan kharaj dari tanah berdasarkan kadar kandungan tanahnya. Apabila kelebihan tersebut dari zakat, maka kelebihan tersebut harus disimpan di dalam Baitul Mal hingga ditemukan delapan ashnaf yang mendapatkan Diwan harta tersebut. Maka, ketika ditemukan kelebihan tersebut akan dibagikan kepada yang bersangkutan. Apabila kelebihan tersebut berasal dari harta yang diwajibkan kepada kaum muslimin, maka kewajiban tersebut dihentikan dari mereka, dan mereka dibebaskan dari pembayaran tersebut. ${ }^{29}$

\footnotetext{
${ }^{28}$ Ibid., hal. 140.

${ }^{29}$ Ibid., hal. 142.
} 


\section{Prinsip Pengelolaan}

Pengeluaran atau penggunaan harta Baitul Mal menurut uraian Taqiyyuddin An Nabhani (1990) ditetapkan berdasarkan 6 (enam) kaidah berikut, yang didasarkan pada kategori tatacara pengelolaan harta, yaitu:

a. Harta yang mempunyai kas khusus dalam Baitul Mal;

b. Harta yang diberikan Baitul Mal untuk menanggulangi terjadinya kekurangan, serta untuk melaksanakan kewajiban jihad;

c. Harta yang diberikan Baitul Mal sebagai suatu pengganti/kompensasi (badal/ujrah);

d. Harta yang dikelola Baitul Mal yang bukan sebagai pengganti/ kompensasi (badal/ujrah), tetapi yang digunakan untuk kemaslahatan dan kemanfaatan secara umum;

e. Harta yang diberikan Baitul Mal karena adanya kemaslahatan dan kemanfaatan, bukan sebagai pengganti/kompensasi (badal/ujrah);

f. Harta yang disalurkan Baitul Mal karena adanya unsur kedaruratan, semisal paceklik/kelaparan, angin taufan, gempa bumi, atau serangan musuh.

Ad.a. Harta yang mempunyai kas khusus dalam Baitul Mal, yaitu harta zakat.

Harta tersebut adalah hak delapan ashnaf yang akan diberikan kepada mereka, bila harta tersebut ada. Apabila harta dari bagian zakat tersebut ada pada Baitul Mal, maka pembagiannya diberikan pada delapan ashnaf yang disebutkan di dalam Al Qur'an sebagai pihak yang berhak atas zakat, serta wajib diberikan kepada mereka. Apabila harta tersebut tidak ada, maka kepemilikan terhadap harta tersebut bagi orang yang berhak mendapatkan bagian tadi telah gugur. Dengan kata lain, bila di dalam Baitul Mal tidak terdapat harta dari bagian zakat tersebut, maka tidak seorang pun dari delapan ashnaf tadi yang berhak mendapatkan bagian zakat. Dan tidak akan dicarikan pinjaman untuk membayar zakat tersebut, berapapun jumlah hasil pengumpulannya.

Ad.b.Harta yang diberikan Baitul Mal untuk menanggulangi terjadinya kekurangan, serta untuk melaksanakan kewajiban jihad.

Yang termasuk dalam kelompok ini, misalnya nafkah untuk para fakir miskin dan ibnu sabil, serta nafkah untuk keperluan jihad. Hak 
mendapatkan pemberian untuk keperluan ini tidak ditentukan berdasarkan adanya harta tersebut. Jadi hak tersebut merupakan hak yang bersifat tetap, baik harta tersebut ada maupun tidak ada di dalam Baitul Mal. Apabila harta tersebut ada, maka seketika itu wajib diberikan. Apabila tidak ada, lalu dikhawatirkan akan terjadi kerusakan/mafsadat karena pemberiannya ditunda, maka negara bisa meminjam harta untuk dibagikan seketika itu juga, berapapun hasil pengumpulan harta tersebut dari kaum muslimin, lalu dilunasi oleh negara. Namun, apabila tidak khawatir terjadi kerusakan, diberlakukanlah kaidah 'fa nazhiratun ila maisarah' (maka hendaklah kita menunggu, sampai ada kelapangan/kecukupan harta). Pembagian harta bisa ditunda, hingga terkumpul dalam jumlah cukup, baru setelah itu diserahkan kepada yang berhak.

Ad.c.Harta yang diberikan Baitul Mal sebagai suatu pengganti/ kompensasi (badal/ujrah)

Yang termasuk dalam hal ini yaitu harta yang menjadi hak orangorang yang telah memberikan jasa, seperti gaji para tentara, pegawai negeri, hakim, tenaga edukatif, dan sebagainya. Hak mendapatkan pemberian ini tidak ditentukan berdasarkan adanya harta tersebut. Jadi hak tersebut merupakan hak yang bersifat tetap, baik harta tersebut ada maupun tidak ada di dalam Baitul Mal. Apabila harta tersebut ada, maka seketika itu wajib diberikan. Apabila tidak ada, maka negara wajib mengusahakannya, dengan cara memungut harta yang diwajibkan atas kaum muslimin. Apabila dikhawatirkan akan terjadi kerusakan, bila pemberian tersebut tidak segera diserahkan, maka negara harus meminjam harta untuk diberikan seketika itu juga, berapapun jumlah hasil pengumpulan hartanya dari kaum muslimin, kemudian negara melunasinya. Apabila tidak khawatir akan terjadi kerusakan, maka diberlakukanlah kaidah 'fa nazhiratun ila maisarah.' (maka hendaklah kita menunggu, sampai ada kelapangan/kecukupan harta) dimana pembagian hartanya bisa ditunda, hingga harta tersebut terkumpul baru setelah itu diserahkan kepada yang berhak.

Ad.d.Harta yang dikelola Baitul Mal yang bukan sebagai pengganti/ kompensasi (badal/ujrah), tetapi yang digunakan untuk kemaslahatan dan kemanfaatan secara umum. 
Yang termasuk di dalam harta ini, misalnya sarana jalan, air, bangunan masjid, sekolah, rumah sakit, dan sarana-sarana lainnya, yang keberadaanya dianggap sebagai sesuatu yang urgen, dimana umat akan mengalami penderitaan/ mudharat jika sarana-sarana tersebut tidak ada. Hak mendapatkan pemberian untuk keperluan ini tidak ditentukan berdasarkan adanya harta tersebut. Hak tersebut bersifat tetap, baik pada saat harta tersebut ada maupun tidak. Apabila di dalam Baitul Mal ada harta, maka wajib disalurkan untuk keperluan tersebut. Apabila di dalam Baitul Mal tidak ada harta, maka kewajibannya berpindah kepada umat, sehingga harta tersebut bisa dikumpulkan dari umat secukupnya untuk memenuhi pengeluaran-pengeluaran yang bersifat tetap tersebut.

Ad.e. Harta yang diberikan Baitul Mal karena adanya kemaslahatan dan kemanfaatan, bukan sebagai pengganti/kompensasi (badal/ujrah). Hanya saja, umat tidak sampai tertimpa penderitaan/mudharat karena tidak adanya pemberian tersebut. Misalnya pembuatan jalan kedua/alternatif setelah ada jalan yang lain, atau membuka rumah sakit baru sementara dengan adanya rumah sakit yang lain sudah cukup, atau membuka jalan yang dekat, sementara orang-orang bisa menemukan jalan lain yang jauh, ataupun yang lainnya. Hak mendapatkan pemberian ini ditentukan berdasarkan adanya harta tersebut. Kalau di dalam Baitul Mal terdapat harta, wajib disalurkan untuk keperluan-keperluan tersebut. Apabila di dalam Baitul Mal tidak terdapat harta, maka kewajiban tersebut gugur dari Baitul Mal. Kaum muslimin juga tidak wajib membayar untuk keperluan ini, sebab sejak awal ia tidak wajib bagi kaum muslimin.

Ad.f. Harta yang disalurkan Baitul Mal karena adanya unsur kedaruratan, semisal paceklik/kelaparan, angin taufan, gempa bumi, atau serangan musuh. Hak memperoleh pemberian tersebut tidak ditentukan berdasarkan adanya harta tersebut. Jadi merupakan hak yang tetap, baik pada saat harta tersebut ada maupun tidak. Apabila harta tersebut ada, maka wajib disalurkan seketika itu juga. Apabila harta tersebut tidak ada, maka kewajibannya meluas kepada kaum muslimin, sehingga harta tersebut wajib dikumpulkan dari kaum muslimin seketika itu juga. Kemudian harta tersebut diletakkan di dalam Baitul Mal untuk disalurkan kepada yang berhak. Apabila dikhawatirkan akan terjadi penderitaan (mafsadat) karena 
penyalurannya ditunda hingga terkumpul semuanya, negara wajib meminjam harta, lalu meletakkannya dalam Baitul Mal, dan seketika itu disalurkan kepada yang berhak. Kemudian hutang tersebut dibayar oleh negara dari harta yang dikumpulkan dari kaum muslimin

\section{Fungsi BMT dalam Rangka Perlindungan Hukum Terhadap Nasabah Penyimpan Dana}

Satu pertanyaan penting yang perlu dikemukakan mengenai bagaimanakah kedudukan BMT dalam konteks perekonomian Islam modern, terutama dalam rangka menjalankan fungsi sebagai lembaga penjamin simpanan dan perlindungan hukum bagi nasabah penyimpan dana? Pada hakikatnya pengembangan institusi dan kebijakan dalam ekonomi Islam tidak memiliki ketentuan baku kecuali apa yang telah digariskan dalam syariat. Khususnya dalam pembentukan departemen dan kebijakan strategi pengkoleksian dan penggunaan pendapatan Negara, sebenarnya juga tergantung pada perkembangan atau kondisi perekonomian Negara pada satu waktu tertentu. Artinya pengembangan institusi dan kebijakan ekonomi tidaklah terikat pada apa yang telah dilakukan oleh para pemimpin-pemimpin terdahulu, peran ijtihad dengan mempertimbangkan keadaan kontemporer menjadi sangat menentukan arah dan bentuk institusi dan kebijakan ekonomi.

Hal ini cukup dipahami, seperti yang telah diketahui, pada masa Rasulullah SAW hingga kepemimpinan Abu Bakar, pengumpulan dan pendistribusian dana zakat serta pungutan-pungutan lainnya dilakukan secara serentak. Artinya pendistribusian dana tersebut langsung dilakukan setelah pengumpulan, sehingga para petugas Baitul Mal selesai melaksanakan tugasnya tidak membawa sisa dana untuk disimpan. Sedangkan pada masa Umar Bin Khattab, pengumpulan dana ternyata begitu besar sehingga diambil keputusan untuk menyimpan untuk keperluan darurat. Dengan keputusan tersebut, maka Baitul Mal secara resmi dilembagakan, dengan maksud awal untuk pengelolaan dana tersebut.

Sehingga dalam perjalanan selanjutnya peran dan fungsi lembaga Baitul Mal sebagai bendahara Negara dan dalam konteks perekonomian modern, lembaga ini dikenal dengan Lembaga Keuangan (treasury house of the state). Fungsi Baitul Mal pada hakikatnya mengelola keuangan negara menggunakan akumulasi dana yang berasal dari pos-pos penerimaan seperti Zakat, Kharaj, Jizyah, Khums, Fay', dan lain-lain, dan dimanfaatkan untuk melaksanakan 
program-program pembangunan ekonomi, sosial, pertahanan, keamanan, penyebaran fikrah Islam melalui diplomasi luar negeri dan semua program pembangunan yang menjadi kebutuhan negara.

Merujuk pada apa yang telah dijelaskan oleh Qardhawi tentang institusi Baitul Mal, dalam operasionalnya, salah satu kebijakan pengelolaan pendapatan Negara adalah ketika dana yang dimiliki departemen sedekah (zakat) yang fungsinya memenuhi kebutuhan dasar warga negara kurang, maka dapat menggunakan dana dari departemen lain yaitu departemen pajak dan upeti. Namun pada masa klasik Islam hal ini dilakukan dengan skema hutang, artinya jika suatu saat departemen sedekah sudah memiliki kecukupan dana, maka hutang tadi harus dilunasi pada departemen pajak dan upeti. Tahapan penggunaan keuangan negara ini sesuai dengan yang dijelaskan sebelumnya, dimana sumber keuangan negara utama adalah zakat, kemudian fay' dan pajak. Jika masih juga kekurangan maka negara akan melakukan skema takaful, dimana semua harta dikumpulkan negara dan dibagikan sama rata.

Berdasarkan kenyataan tersebut, maka kelembagaan BMT sebagai lembaga keuangan (treasury house of the state), dapat melakukan pengembangan fungsi dan perannya dalam perekonomian Islam khususnya sektor perbankan syari'ah, sebagai lembaga penjamin simpanan bagi nasabah penyimpan dana, tanpa melepaskan tugas dan fungsi utamanya yaitu sebagai institusi yang menjalankan fungsi-fungsi ekonomi dan sosial dari sebuah Negara secara luas dari sekedar lembaga penjamin simpanan.

\section{Simpulan}

Dari seluruh uraian yang telah dipaparkan dapatlah ditarik beberapa kesimpulan umum sebagai berikut:

LPS merupakan merupakan lembaga hukum publik yang bergerak dalam lapangan masyarakat umum, bukan secara individu. Kedudukan LPS adalah merupakan suatu lembaga independen, yang berfungsi menjamin simpanan nasabah penyimpan dan turut aktif dalam memelihara stabilitas sistem perbankan sesuai dengan kewenangannya. Dalam melaksanakan fungsi. Dalam melaksanakan fungsi tersebut, LPS memiliki tugas, antara lain: (1) merumuskan dan menetapkan kebijakan pelaksanaan penjaminan simpanan; (2) melaksanakan penjaminan simpanan; (3) merumuskan dan menetapkan kebijakan dalam rangka turut aktif memelihara stabilitas sistem perbankan; (4) merumuskan, menetapkan, dan melaksanakan kebijakan penyelesaian Bank Gagal yang tidak berdampak sistemik; 
dan (5) melaksanakan penanganan Bank Gagal yang berdampak sistemik. Dalam rangka perlindungan hukum terhadap nasabah penyimpan dana menurut UU LPS, LPS belum benar-benar mendapatkan perlindungan hukum, khususnya dalam hubungan hukum publik antara LPS dengan nasabah penyimpan dana.

Dalam rangka perlindungan hukum terhadap nasabah penyimpan dana menurut UU LPS, LPS belum benar-benar mendapatkan perlindungan hukum, khususnya dalam hubungan hukum publik antara LPS dengan nasabah penyimpan dana.

Dalam hukum Islam tidak dikenal LPS, tetapi dikenal suatu lembaga yang memili salah fungsi sebagaimana fungsi LPS yaitu Baitul Mal wat Tamwil (BMT). Kedudukan BMT dalam Hukum Islam, adalah: Pertama, merupakan lembaga hukum publik yang bergerak dalam lapangan masyarakat umum, bukan secara individu. Baitul Mal tidak hanya menangani sebagian aspek kegiatan ekonomi umat, melainkan sebuah lembaga yang mengurusi segala pemasukan dan pengeluaran dari Pemerintahan Islam (Khilafah). Kedua, bagian dari institusi negara yang mengurusi pemasukan dan pengeluaran negara tersebut, telah dipraktekkan dengan berbagai nuansa kelebihan dan kekurangannya dalam sejarah Islam sejak masa Rasulullah, diteruskan oleh para khalifah sesudahnya, hingga kehancuran Khilafah di Turki tahun 1924.

Terdapat perbedaan, antara LPS dan Baitul Mal sebagai lembaga penjaminan simpanan, yaitu bahwa LPS dalam sistem perbankan konvensional, pemasukan hanya berasal dari satu sumber yaitu nasabah bank dan peruntukkan juga hanya bagi nasabah peyimpan dana. Sedangkan dalam konsep Baitul Mal, pendapatan Baitul Mal diperoleh dari berbagai sumber sesuai dengan hukum-hukum syara', maka peruntukkan atau pengeluarannya pun harus sesuai dengan apa yang telah ditetapkan oleh hukum syara' yang bersifat qathi'/pasti, yaitu: (1) Bagian fa'i dan kharaj untuk membiayai: seksi dar al-khilafah, seksi mashalih daulah, seksi santunan, seksi jihad, seksi urusan darurat, dan seksi anggaran belanja negara-pengendalian umumlembaga penjamin keuangan (LPS); (2) Bagian pemilikan umum untuk membiayai: seksi jihad, Biro mashalih daulah/pelayanan publik, seksi penyimpanan harta milik umum dan untuk seksi urusan darurat/bencana alam; dan (3) Bagian shodaqoh/zakat untuk: seksi jihad fi sabilillahi, seksi penyimpanan harta zakat, 8 (delapan) golongan ashnaf.

Dengan demikian dalam BMT hanya bagian Fa'i-Kharaj, khususnya seksi anggaran belanja negara-pengendalian umum-lembaga penjamin keuangan (LPS) yang dapat diproyeksikan sebagai lembaga penjamin simpanan dengan cara mengambil sumber dana dari nasabah penyimpan dana dan salah satu penggunaa adalah sebagai penjaminan simpanan bagi nasabah itu sendiri. 


\section{Daftar Pustaka}

\section{Buku}

Algra, N. E., Duyvendijk, K. Van., Simorangkir, J.C.T., dan Batoeah, Boerhanoeddin Soetan. Pengantar Ilmu Hukum, Jakarta: Bina Cipta, 1983.

An Nabhani, Taqiyyuddin. An Nizham Al Iqtishadi Fi Al Islam, Cetakan IV, Beirut: Darul Ummah, 1990.

Dahlan, Abdul Aziz, et.al., Ensiklopedi Hukum Islam, Cetakan II, Jakarta: PT Ichtiar Baru van Hoeve, 1999.

Djumhana, Muhamad. Hukum Perbankan Di Indonesia, Bandung: PT Citra Aditya Bakti, 1996.

Fuadi, Munir. Hukum Perbankan Modern Buku Kesatu, Bandung: PT Citra Aditya Bakti, 1999.

Hadjon, Philipus M. Tanggung Gugat Lembaga Penjamin Simpanan Sebagai badan Hukum Menurut Undang-Undang No.24 Tahun 2004, Seminar Nasional LPS Sebagai Wahanan Perlindungan Dana Simpanan Nasabah, Fakultas Hukum Unair, Surabaya, 1 Juli 2006.

Hakim, Cecep Maskanul. Konsep Pengembangan Baitul Mal, Paper Seminar Ekonomi Islam ICMI Bandung, 1995.

Islahi, Abdul Azim. Economic Concepts of Ibn Taimiyah, The Islamic foundation, Leicester - UK, 1996/1417H, 1996.

Qaradhawi, Yusuf. Norma dan Etika Ekonomi Islam. Jakarta: Gema Insani Press, 1997.

Qardhawy, Yusuf. Hukum Zakat, Jakarta: Pustaka Litera Antar Nusa, 1988.

Sitompul, Zulkarnain. Dasar Filosofi Keberadaan Lembaga Penjamin Simpanan, Seminar Nasional LPS Sebagai Wahanan Perlindungan Hukum Dana Simpanan Nasabah, Fakultas Hukum Unairm Surabaya, 1 Juli 2006.

Symon, Jr. Edward L., dalam Zulkarnain Sitompul, Dasar Filosofi Keberadaan Lembaga Penjamin Simpanan, Seminar Nasional LPS 
Sebagai Wahanan Perlindungan Hukum Dana Simpanan Nasabah, Fakultas Hukum Unair Surabaya, 1 Juli 2006.

Tim DD-FES-BMT. Pedoman Kemitraan Dompet Dhuafa Republika-FESBMT, Jakarta: Dompet Dhuafa Republika, 1997.

Zallum, Abdul Qadim. Al Amwal Fi Daulah Al Khilafah, Cetakan I. Beirut: Darul 'Ilmi Lil Malayin, 1983.

\section{Internet}

Ma'ruf, Farid. Baitul Mal, Tinjauan Historis dan Konsep Idealnya, $<$ http://msi-uii.net/baca.asp?katagori=rubrik\&menu=ekonomi\&baca $=$ artikel\&id=75>, diakses 1 Desember 2010.

$<$ http://1.bp.blogspot.com/_taMajVQWOio/RudYVH1HzYI/AAAAAAAAACo /n9ZZ3_QyEZA/s1600-h/public+finance.JPG/baitul-mal-dalamkeuangan-publik.html>, diakses tanggal 1 Desember 2010.

$<$ http://abiaqsa.blogspot.com/baitul-mal-dalam-keuangan-publik.html>, diakses tanggal 1 Desember 2010. 